African Crop Science Journal by African Crop Science Society is licensed under a Creative Commons Attribution 3.0 Uganda License. Based on a work at www.ajol.info/ and www.bioline.org.br/cs DOI: http://dx.doi.org/10.4314/acsj.v24i1.13S

\title{
INTEGRATING CASSAVA VARIETIES AND Typhlodramulus aripo TO SUSTAIN BIOLOGICAL CONTROL OF CASSAVA GREEN MITE
}

\author{
R. MOLO, W. AOOL, S. ADUMO and D.L. MUTISYA ${ }^{1}$ \\ National Agricultural Research Laboratories, P. O. Box 7065, Kampala, Uganda \\ ${ }^{1}$ KARI-Katumani, P. O. Box 340-90100, Machakos, Kenya \\ Corresponding author: richardmolo7@gmail.com
}

\begin{abstract}
The cassava green mite (CGM), Mononychellus tanajoa, is a pest that reduces root yield of cassava (Manihot esculenta Crantz) by $30-80 \%$ in the cassava belts of Africa. The objective of this study was to identify cassava varieties that enhance abundance and persistence of Typhlodramulus aripo on cassava and increase its efficiency in controlling CGM. Nine cassava (Manihot esculenta Crantz) varieties were evaluated in Kenya based on CGM abundance and HCN of leaves for their ability to sustain low CGM populations to enhance biocontrol of T. aripo. Cassava fields were surveyed in five agro-ecological zones in Uganda and samples of cassava apices were analysed for cassava varieties to sustain high population of $T$. aripo. In the screening study of CGM abundance and HCN content of leaves and the lowest cumulative CGM population densities ( $<1200$ mites/leaf) were recorded on MM97/3567, Tajirika and MM96/9308, with the lowest cyanide content of leaves, 8.5 $\pm 4.9,12.5$ \pm 3.2 and $12.3 \pm 2.5 \mathrm{mg} \mathrm{kg}^{-1}$, respectively. Cassava varieties with hairy and non-hairy tips sustained $T$. aripo with highest densities ( 0.96 actives per tip) on hairy TME14. High T. aripo population densities corresponded to high densities of hairs on cassava tips. There were significant inverse linear relationships between CGM densities and T. aripo on TME14 at moderate CGM population densities (CGM damage level 2).
\end{abstract}

Key Words: Cyanide, Manihot esculenta, Mononychellus tanajoa

\section{RÉSUMÉ}

Le tantinet vert de la cassave (CGM), Mononychellus tanajoa, est un insecte nuisible qui réduit la production de racine de cassave (Manihot esculenta Crantz) de 30-80\% dans les ceintures de cassave de l'Afrique. L'objectif de cette étude était d'identifier des variétés de cassave qui améliorent l'abondance et la persistance de Typhlodramulus aripo sur la cassave et augmentent son efficacité dans le contrôle de CGM. Neuf cassave (Manihot esculenta Crantz) les variétés ont été évaluées au Kenya basé sur l'abondance CGM et HCN de part pour leur capacité de soutenir bas des populations de CGM pour améliorer biocontrol de T. aripo. Les champs de cassave ont été étudiés dans cinq zones agro-écologiques en Ouganda et les échantillons de sommets de cassave ont été analysés pour les variétés de cassave pour soutenir la haute population de T. aripo. Dans l'étude de projection d'abondance CGM et de contenu de HCN de congés et des densités démographiques CGM cumulatives les plus basses $(<1200$ tantinets/feuille) ont été enregistrés sur MM97/3567, Tajirika et MM96/9308, avec le contenu de cyanure le plus bas de congés, $8.5 \pm 4.9,12.5 \pm 3.2$ et $12.3 \mathrm{~kg}$ de $2.5 \mathrm{mgs} \pm 1$, respectivement. Les variétés de cassave avec les bouts poilus et non-poilus ont soutenu T. aripo avec les plus hautes densités ( 0.96 actives par bout) sur TME14 poilu. Haut $T$. aripo les densités démographiques a correspondu à de hautes densités de hairs sur les bouts de cassave. Il y avait des rapports linéaires inverses significatifs entre les densités CGM et T. aripo sur TME14 aux densités démographiques CGM modérées (le niveau de dommage de CGM 2).

Mots Clés: le Cyanure, Manihot esculenta, Mononychellus tanajoa 


\section{INTRODUCTION}

Cassava (Manihot esculenta Crantz) is attacked by cassava green mite (CGM), Mononychellus tanajoa (Acari: Tetranychidae), an introduced pest in Africa, in 1970s (Nyiira, 1972). Since its first appearance in East Africa, the pest has expanded its distribution to the entire cassava growing belts, where it causes estimated yield losses ranging between 30-80 \% (Yanninek et al., 1989). Climatic and soil factors influence the population dynamics of CGM with positive or negative effects. To date, control of CGM in Africa has relied mainly on predatory mite species, of the family Phytoseiidae. Initial biological control efforts involved evaluation of over 11 phytoseiid mite species, of Colombian and Brazilian origin, during 1986-1993 (Yaninek et al., 1993). But none of these species became successfully established in Africa. However, in the later years of evaluation, one predatory mite species, Typhlodramulus aripo, was introduced from Brazil (Yaninek and Hanna, 2003). Through field releases, the species was identified as the most successful biological control agent and since then, it has been considered as the key predator of CGM in the cassava belts of Africa (Yaninek et al., 1991; Yaninek et al., 1993; Hanna and Toko, 2003).

Typhlodramulus aripo was imported by the International Institute of Tropical Agriculture (IITA), under CGM Biological Control Regional project, and released in East Africa in 1994. Following its establishment, subsequent studies demonstrated the potential of $T$. aripo in increasing cassava production in both local and improved cassava varieties (Karuiki et al., 2004; Molo, 2006, unpublished). This predator has unique ecological requirements, that improve its efficiency in controlling CGM. It inhabits the apex of cassava and all its reproduction occurs in the apex (Onzo et al., 2003). It is a nocturnal predator and encounters CGM prey as it migrates from cassava tips to the leaves during feeding. Studies by Zundel (2006) indicate that drought causes $T$. aripo to migrate from cassava apices to wild plants, leading to reduction in predation of CGM prey on cassava.

The East African region suffers frequent drought, thus facilitating proliferation of CGM populations (Skovgard et al., 1993). Gnanvossou et al. (2001) and Magalhaes et al.(2002) found that $T$. aripo has a high searching ability for CGM, at very low prey densities, which increases its efficiency as a biocontrol agent. Cassava varieties that sustain relatively low CGM population will facilitate biological control by $T$. aripo at a fast rate. Appropriate cassava varieties that support low CGM populations and increase persistence of $T$. aripo on cassava are needed to facilitate biological control of CGM. The objective of this study was to identify cassava varieties to aid abundance and persistence of $T$. aripo on cassava and increase its efficiency in controlling CGM.

\section{MATERIALS AND METHODS}

Cassava varietal screening. Nine cassava varieties, including MM99005, MM990183 and X-Mariakani from the eastern, Kaleso, Karibuni, Tajirika from coastal and MM97/3567, MM96/ 2480 and MM96/9308 from western Kenya were planted in the eastern lowlands, western midlands and the humid coastal lowlands of Kenya. The experiment was carried in screen houses to exclude white fly vectors of cassava mosaic and brown streak diseases that affect cassava leaves. Cassava green mites were collected from the coastal Kenya lowlands, and 10 individuals of CGM adult motiles were released on each cassava variety. On day five, after mite introduction, the number of CGM per leaf on each cassava variety was determined, by counting CGM actives, according to Yaninek et al. (1989), every three days for up to 55 days. Leaf samples representing CGM damage scores on a scale 1-5 where, $1=$ no damage and 5 severe damage, were picked in paper bags. They were brittle oven-dried at $60{ }^{\circ} \mathrm{C}$ for 4 days, and weighed.

The loss in leaf biomass was determined as weight difference between damaged and undamaged leaves. Cassava leaf cyanide ( $\mathrm{HCN}$ $\mathrm{mgkg}^{-1}$ ) content of CGM damage leaves at damage score 1-5, was determined by Picric Acid method.

Persistence and impact. A follow up of previous field releases (1994-98) of T. aripo in Uganda was conducted in April and December 2013, during 
the rainy and dry season, respectively, basing on the knowledge of $T$. aripo ecological characteristics that they reside entirely in bracts of cassava apices. Cassava fields were sampled at intervals of $5-10 \mathrm{Km}$, along major roads, and in each field, 20 cassava plants were examined. The CGM population was counted on the first fully opened leaf of each cassava plant. CGM leaf damage was assessed on a scale 1-3; where $1=$ clean plants, $2=$ less than $75 \%$ of leaves showing chlorosis, and $3=$ over $75 \%$ of leaves showing chlorosis. One cassava tip on each of the 20 plants was examined for $T$. aripo and recorded as present or absent to determine the total number of $T$. aripo infested plants. Five cassava tips were randomly decapitated from each field and put in vials containing $70 \%$ alcohol. They were dissected under a binocular microscope, and $T$. aripo actives were counted. One outer bract on each cassava tip was removed and placed under a dissecting microscope, and the total number of hairs on it was recorded. A total of 5 agroecological zones, each comprising of 4-5 districts, were randomly selected and surveyed.

Statistical analysis. Cumulative CGM numbers were calculated from CGM population data in the screening trial. Numbers of hairs on cassava tips,
CGM and T. aripo were $\log \mathrm{x}+1$ transformed and the number of $T$. aripo infested plants were converted into percentages and arcsine square root transformed. Data on CGM, HCN, T. aripo, and percentage $T$. aripo infested plants were analysed by ANOVA, using Stata Statistical Software, Release 13, and means separated using Tukey test.

\section{RESULTS}

CGM abundance and hydrocyanic content. The CGM population increased with time (Fig. 1), and cassava varieties MM97/3567sustained the lowest cumulative CGM population (300 mites per leaf), over a period of 55 days. Varieties Tajirika (1146 mites per leaf) and MM96/9308 (1186 mites per leaf) sustained intermediate CGM population densities. The highest cumulative CGM population (1665.7 actives per tip) was on Mariakani.

Cassava varieties; Kaleso, Karibuni and MM96/2480, showed the highest level of $\mathrm{HCN}$ in correspondence with high CGM densities. On the other hand, varieties MM97/3567, Tajirika and MM99005 showed the lowest cyanogenic potential of $8.5 \pm 4.9,12.5 \pm 3.2$ and $12.3 \pm 2.5$ $\mathrm{mgkg}^{-1}$, respectively (Fig. 2). High leaf cyanide

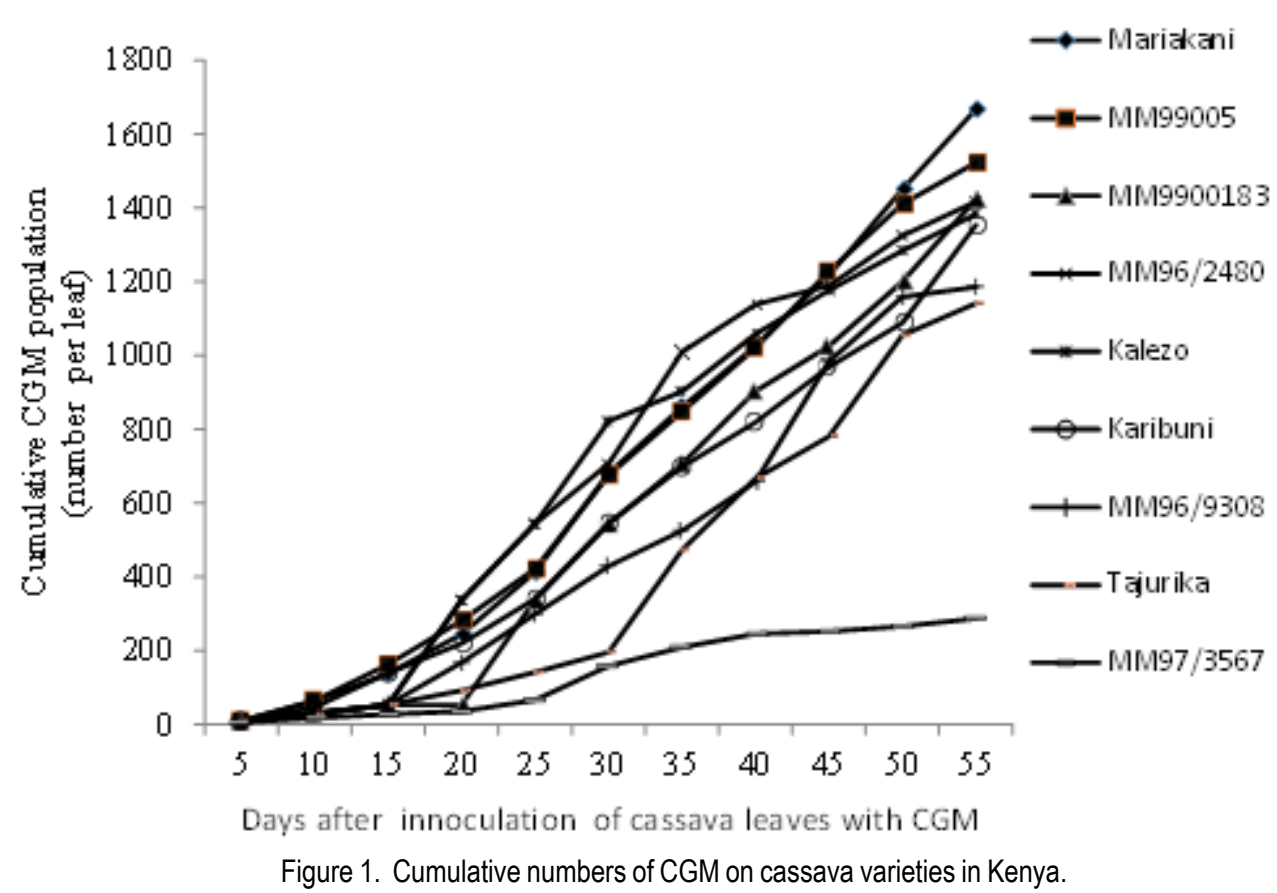

Figure 1. Cumulative numbers of CGM on cassava varieties in Kenya. 
$(\mathrm{HCN})$ content corresponded with higher leaf biomass loss (\%).

Hairiness of cassava varieties. Hairiness of tips of several cassava varieties contributed to the abundance of $T$. aripo (Fig. 3). The cassava varieties with hairy and non-hairy tips, sustained T. aripo with population densities ranging between 0.08-1.0 actives per tip. The hairy cassava varieties included TME2961, NASE3,
Akena, NASE12, NASE14 and TME14. Hair densities ranged from 1.02-1.67 hairs per bract, with the highest on TME14 and the lowest on TME2961. There were no hairs on the tips of Bao, NASE4 and TME204.

\section{Persistence and impact on CGM of T. aripo.} Low to moderate CGM population densities were considered in assessing T. aripo persistence, as the impact of the predator can be easily

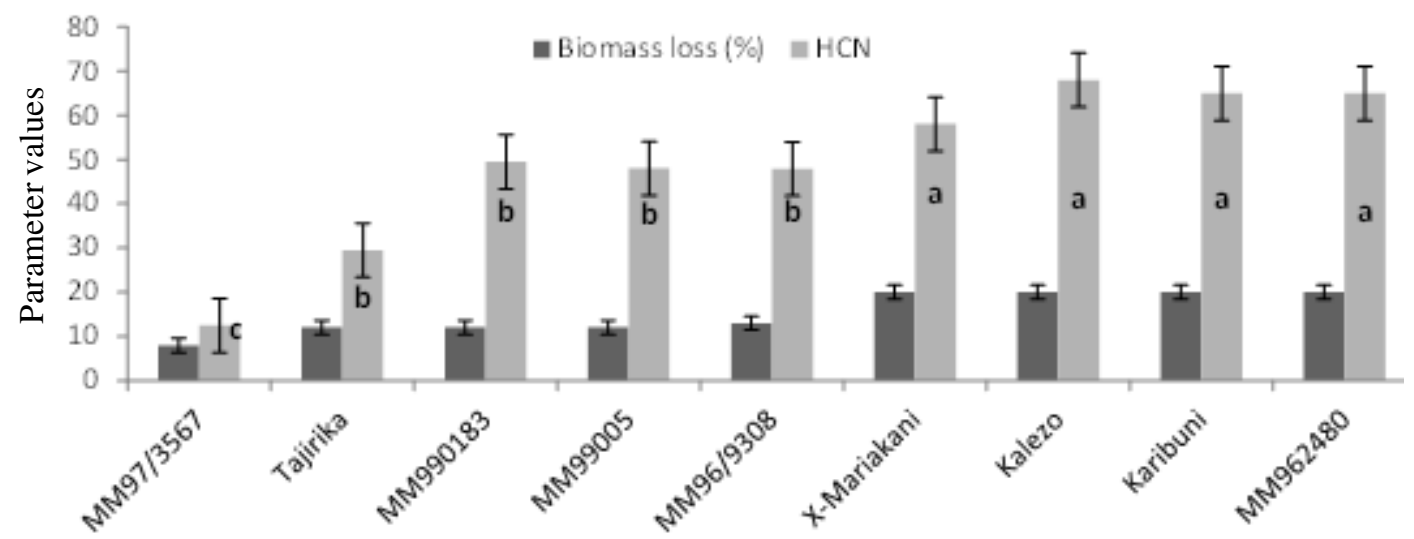

Cassava varieties

Figure 2. Cyanide content $\left(\mathrm{HCN} \mathrm{mgkg}^{-1}\right)$ and leaf biomass loss $(\%)$ for cassava varieties. Case letters denote significance $(\mathrm{P}<$ 0.05) levels.

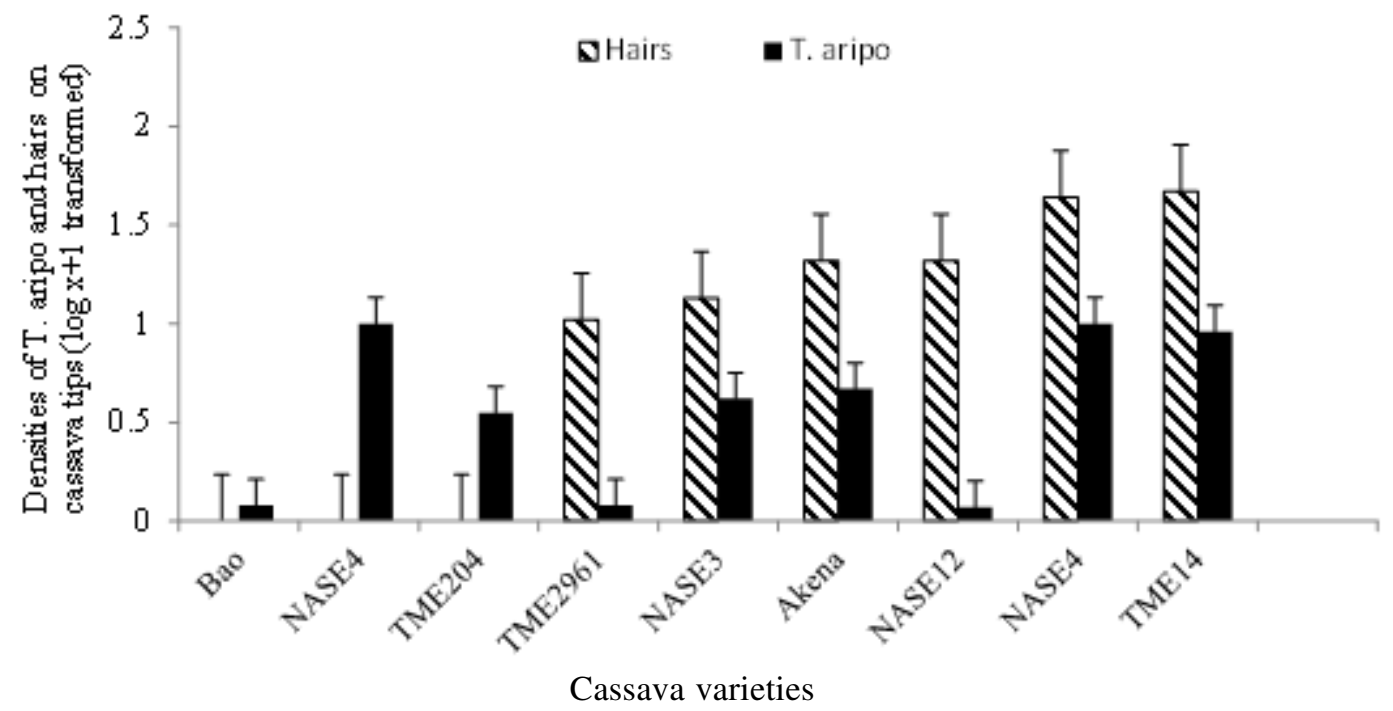

Figure 3. Relationship between tip hairiness and abundance of $T$. aripo on cassava varieties in Uganda. Vertical bars indicate standard errors. 
demonstrated on cassava at these densities. Northern Moist Farmlands, NASE3 in Southern Table 1 shows variability of CGM and T. aripo and Eastern Lake Kyoga basin and TME14 in infestation on cassava varieties in various agro- Western Medium High Farmlands. In December ecological zones of Uganda at different dates. 2013, low to moderate CGM densities were found During April 2013, low to moderate CGM on TME 204 inNorthwestern and West Nile population densities (0-0.82 mites per leaf) were Farmlands and TME14 in Southern and Eastern found on TME2961, Bao, TME14 and TME204 in Lake Kyoga basin. In April, T. aripo was found

TABLE 1. Population densities of T. aripo on cassava varieties in various agro ecological zones during first rains in April and dry season in December 2013

\begin{tabular}{|c|c|c|c|c|}
\hline Agro ecological zone & Variety & $\begin{array}{l}\text { CGM density } \\
\text { leaf }^{-1}\end{array}$ & $\begin{array}{l}\text { T. aripo density } \\
\text { tip }^{-1}\end{array}$ & $\begin{array}{l}\text { T. aripo infested } \\
\text { plants (\%) }\end{array}$ \\
\hline
\end{tabular}

First rains April 2013

Northern moist farmlands

\begin{tabular}{|c|c|c|c|}
\hline TME2961 & $0.00^{\mathrm{d}}(0.00)$ & $0.06^{a}(0.15)$ & $0.00^{\mathrm{e}}(0.00)$ \\
\hline Bao & $0.00^{d}(0.00)$ & $0.03^{a}(0.08)$ & $0.00^{\mathrm{e}}(0.00)$ \\
\hline NASE12 & $1.05^{\mathrm{abcd}}(63.02)$ & $0.05^{a}(0.15)$ & $7.78^{\mathrm{de}}(6.68)$ \\
\hline NASE3 & $1.83^{a}(68.67)$ & $0.15^{\mathrm{a}}(0.47)$ & $25.00^{b}(31.10)$ \\
\hline TME14 & $0.27^{\mathrm{d}}(1.63)$ & $0.05^{\mathrm{a}}(0.14)$ & $1.23^{e}(0.24)$ \\
\hline TME204 & $0.23^{d}(0.70)$ & $0.00^{\mathrm{a}}(0.00)$ & $7.50^{\text {de }}()$ \\
\hline Akena & $1.39^{\text {abod }}(25.27)$ & $0.00^{\mathrm{a}}(0.00)$ & $17.50^{\text {cde }}(6.6)$ \\
\hline NASE3 & $0.63^{\mathrm{bc}}(13.32)$ & $0.18^{a}(0.74)$ & $18.79^{b c}(14.71)$ \\
\hline TME14 & $1.58^{\mathrm{abc}}(36.82)$ & $0.42^{\mathrm{a}}(2.76)$ & $34.06^{\mathrm{bc}}(37.32)$ \\
\hline TME204 & $1.04^{\mathrm{abcd}}(0.51)$ & $0.00^{\mathrm{a}}(0.00)$ & $20.72^{\mathrm{cd}}(35.00)$ \\
\hline Akena & $1.98^{\mathrm{a}}(261.09)$ & $0.23^{\mathrm{a}}(0.75)$ & $0.00^{\mathrm{e}}(0.00)$ \\
\hline TME14 & $0.34^{\mathrm{cd}}(3.00)$ & $0.17^{a}(0.63)$ & $49.50^{\mathrm{ab}}(56.26)$ \\
\hline NASE14 & $1.27^{\mathrm{abcd}}(18.70)$ & $0.00^{\mathrm{a}}(0.00)$ & $50.75^{\mathrm{ab}}(59.97)$ \\
\hline
\end{tabular}

Dry season December 2013

\begin{tabular}{|c|c|c|c|c|}
\hline Northern moist farmlands & TME14 & $1.18^{\mathrm{abcd}}(17.17)$ & $0.14^{\mathrm{a}}(0.59)$ & $\left.20.36^{\text {cd }} 20.53\right)$ \\
\hline & NASE3 & $1.18^{\mathrm{abcd}}(49.17)$ & $0.05^{\mathrm{a}}(0.10)$ & $38.91^{\text {bc }}(39.99)$ \\
\hline & TME204 & $1.31^{\mathrm{abcd}}(119.52)$ & $0.27^{\mathrm{a}}(1.22)$ & $6.37^{\mathrm{de}}(2.50)$ \\
\hline & NASE12 & $1.21^{\mathrm{abcd}}(15.40)$ & $0.00^{\mathrm{a}}(0.00)$ & $0.00^{e}(0.00)$ \\
\hline Northwestern farmlands & TME204 & $0.19^{d}(0.53)$ & $0.03^{a}(0.07)$ & $15.00^{\text {cde }}(16.67)$ \\
\hline Southern and Eastern Lake Kyoga basin & NASE3 & $1.80^{\mathrm{ab}}(62.13)$ & $0.14^{\mathrm{a}}(0.49)$ & $23.67^{\mathrm{bcd}}(19.96)$ \\
\hline & TME14 & $0.82^{\text {bcd }}(9.64)$ & $0.30^{\mathrm{a}}(1.34)$ & $31.03^{\text {bc }}(9.64)$ \\
\hline & NASE14 & $1.25(16.70)$ & $0.48^{a}(2.03)$ & $75.50^{\mathrm{a}}(93.33)$ \\
\hline West Nile farmlands & TME204 & $0.21^{d}(0.63)$ & $0.17^{a}(1.00)$ & $40.61^{\mathrm{bc}}(42.50)$ \\
\hline Western Medium High Farmlands & TME14 & $1.36^{\mathrm{a}}(23.36)$ & $0.27^{a}(1.83)$ & $33.75^{\mathrm{bc}}(39.99)$ \\
\hline & TME2961 & $1.32^{\mathrm{a}}(20.00)$ & $0.00^{\mathrm{a}}(0.00)$ & $0.00^{\mathrm{e}}(0.00)$ \\
\hline & Akena & $1.32^{\mathrm{a}}(20.00)$ & $0.00^{\mathrm{a}}(0.00)$ & $0.00^{e}(0.00)$ \\
\hline
\end{tabular}

Figures in parentheses are actual mean numbers of CGM and T. aripo for $\log x+1$ transformed values and actual percentages for arcsine transformed values for percentage T. aripo infested plants; Figures with same superscript letters within a column are not significantly different (Tukey test) 
on TME2961 and Bao in Northern Moist Farmlands in the absence of CGM; but at moderate CGM population densities, T. aripo was found on TME14 in Northern Moist and Western Medium High Farmlands and on TME204 in the Northwestern and West Nile Farmlands in December 2013. Moderate T. aripo infested plants (18.79-49.50\%) were at moderate CGM infestations on NASE3 and TME14 in Southern and Eastern Lake Kyoga basin and TME14 in Western Medium High Farmlands in April, TME14 in Southern and Eastern Lake Kyoga basin and TME204 in West Nile Farmlands in December 2013.

The criterion for selection of optimal cassava variety for persistence of $T$. aripo was based on consistency in presence of $T$. aripo on cassava at different dates and agro-ecological zones. At various CGM leaf damage levels, T. aripo and CGM population densities varied among cassava varieties, in agro-ecological zones, at different sampling dates (Table 2). At CGM leaf damage score 1, Bao, TME2961, NASE12, TME14 and NASE3 sustained T. aripo without CGM. Population densities of $T$. aripo on the varieties ranged from $0.03-0.43$ actives per tip, and differed significantly $(\mathrm{P}=0.002)$ among cassava varieties. At the CGM leaf damage score 2, population densities of CGM were low, moderate and high; and differed significantly $(\mathrm{P}=0.007)$ among cassava varieties.

Variety TME204 did not support T. aripo in the Northern Moist Farmlands and Southern and Eastern Lake Kyoga basin during April; and in December in Northern Moist and Northwestern Farmlands at low CGM densities (0.18-0.23 mites per leaf). At moderate CGM population densities (0.73-0.91 mites per leaf), TME14 supported $T$. aripo populations in Northern Moist and Western Medium High Farmlands during April; and Southern and Eastern Lake Kyoga basin in December 2013, with the highest T. aripo population density ( 0.54 actives per tip) in Western Medium High Farmlands in December 2013. At moderate CGM population densities, NASE3 also supported T. aripo, but only in Southern and Eastern Lake Kyoga basin during April 2013.

A linear regression of abundance of CGM and T. aripo showed the importance of cassava varieties on abundance of CGM and T. aripo (Table 3). At the CGM leaf damage score of 2, TME14 demonstrated significant inverse relationships of abundance of CGM and T. aripo in the Northern Moist Farmlands, during April 2013. Positive significant relationships for TME14 were obtained in Western Medium High Farmlands in April and December. Similarly, at the leaf damage score 2, significant positive relationships of abundance of CGM and T. aripo were found on NASE12 in Southern and Eastern Lake Kyoga basin during December. In other varieties, increasing CGM population densities were linked to increasing T. aripo population and vice versa but these were not significant at different dates and agro-ecological zones.

\section{DISCUSSION}

Cassava varieties showed tolerance to CGM as evidenced by the low cumulative mite densities on MM97/3567 and Tajirika (Fig. 1). Resistance of cassava varieties was inversely related to cyanide levels in their leaves; the most susceptible varieties showing the highest cyanide levels. Chemical plant attributes have been shown to influence the abundance, fecundity and survival rate of insect herbivores in various crops (Cortesero et al., 2000). In studies elsewhere (Riis et al., 2003), high cyanide levels were shown to predispose plants to insect attack through increased feeding, but reduced multiplication rates of insect herbivores.

Basing on the results from this study, the cassava varieties with low cyanide levels have been found to habour low CGM population densities. Therefore, one way to improve the effectiveness of $T$. aripo is to use cassava varieties with low cyanide levels, such as MM97/ 3567 to reduce the multiplication rate of CGM. Under low CGM population densities, T. aripo can adequately bring CGM population under control.

Persistence of T. aripo was demonstrated on cassava varieties based on the hairiness of cassava tips (Fig. 3). Several hairy and non-hairy cassava varieties encouraged high population of T. aripo. Based on tip characteristics, it was clear that hairiness contributes immensely to abundance of $T$. aripo on the cassava varieties. 
TABLE 2. Population densities of T. aripo and CGM on cassava varieties at various CGM leaf damage scores in agro ecological zones during April and December 2013

\begin{tabular}{|c|c|c|c|c|c|c|c|c|}
\hline \multirow[t]{2}{*}{ Sampling date } & \multirow[t]{2}{*}{ Agro ecological zone } & \multirow{2}{*}{$\begin{array}{l}\text { Cassava } \\
\text { variety }\end{array}$} & \multicolumn{2}{|c|}{ Score 1} & \multicolumn{2}{|l|}{ Score 2} & \multicolumn{2}{|c|}{ Score 3} \\
\hline & & & CGM & T. aripo & CGM & T. aripo & CGM & T. aripo \\
\hline \multirow[t]{14}{*}{ Rainy season April 2013} & \multirow[t]{7}{*}{ Northern moist farmlands } & Bao & 0.00 & $0.03 \pm 0.02^{b}$ & - & - & - & - \\
\hline & & TME2961 & 0.00 & $0.06 \pm 0.04^{b}$ & - & - & - & - \\
\hline & & NASE12 & 0.00 & $0.10 \pm 0.06^{\mathrm{ab}}$ & - & - & $2.10 \pm 0.06^{b c}$ & $0.00 \pm 0.00^{b}$ \\
\hline & & TME14 & 0.00 & $0.06 \pm 0.04^{b}$ & $0.73 \pm 0.02^{\text {cd }}$ & $0.04^{c} \pm 0.02$ & - & - \\
\hline & & TME204 & - & - & $0.23 \pm 0.00^{\mathrm{e}}$ & $0.00^{\circ} \pm 0.00$ & - & - \\
\hline & & Akena & - & - & $1.42 \pm 0.03^{\mathrm{a}}$ & $0.00^{c} \pm 0.00$ & - & - \\
\hline & & NASE3 & - & - & & & $1.83 \pm 0.04^{\mathrm{bcd}}$ & $0.15 \pm 0.01^{\mathrm{ab}}$ \\
\hline & Northwestern farmlands & TME204 & - & - & - & - & - & - \\
\hline & \multirow[t]{4}{*}{ Southern and Eastern Lake Kyoga basin } & NASE3 & 0.00 & $0.24 \pm 0.21^{\mathrm{ab}}$ & $0.32 \pm 0.04^{e}$ & $0.19^{\mathrm{ab}} \pm 0.11$ & $1.66 \pm 0.28^{\text {cde }}$ & $0.11 \pm 0.04^{\mathrm{ab}}$ \\
\hline & & TME204 & - & - & $0.18 \pm 0.00^{f}$ & $0.00^{c} \pm 0.00$ & $2.19 \pm 0.23^{\mathrm{ab}}$ & $0.08 \pm 0.01^{\mathrm{ab}}$ \\
\hline & & Akena & - & - & $1.40 \pm 0.00^{\mathrm{a}}$ & $0.15^{a b} \pm 0.01$ & $2.76 \pm 02^{\mathrm{a}}$ & $0.34 \pm 0.01^{\mathrm{ab}}$ \\
\hline & & TME14 & - & - & - & - & $1.58 \pm 0.05^{\text {cde }}$ & $0.42 \pm 0.20^{\mathrm{ab}}$ \\
\hline & \multirow[t]{2}{*}{ Western Medium High farmlands } & TME14 & 0.00 & $0.08 \pm 0.07^{\mathrm{ab}}$ & $0.91 \pm 0.12^{\mathrm{cd}}$ & $0.33^{\mathrm{ab}} \pm 0.07$ & - & - \\
\hline & & NASE14 & - & - & $1.29 \pm 0.00^{\mathrm{ab}}$ & $0.00^{c} \pm 0.00$ & - & - \\
\hline \multirow[t]{12}{*}{ Dry season December 2013} & \multirow[t]{4}{*}{ Northern Moist farmlands } & TME14 & - & - & $1.01 \pm 0.07^{\mathrm{cd}}$ & $0.20^{\mathrm{ab}} \pm 0.10$ & $1.51 \pm 0.08^{\text {cde }}$ & $0.04 \pm 0.00^{\mathrm{ab}}$ \\
\hline & & NASE3 & - & - & $0.34 \pm 0.23^{e}$ & $0.00^{c} \pm 0.00$ & $1.99 \pm 0.03^{\mathrm{bcd}}$ & $0.10 \pm 0.00^{\mathrm{ab}}$ \\
\hline & & TME204 & - & - & $0.23 \pm 0.03^{f}$ & $0.03^{c} \pm 0.00$ & $2.38 \pm 0.02^{b}$ & $0.53 \pm 0.02^{\mathrm{a}}$ \\
\hline & & NASE12 & - & - & $1.21 \pm 0.06^{\mathrm{ab}}$ & $0.00^{c} \pm 0.00$ & - & - \\
\hline & Northwestern farmlands & TME204 & & & $0.19 \pm 0.01^{f}$ & $0.03^{c} \pm 0.03$ & & \\
\hline & \multirow[t]{3}{*}{ Southern and Eastern Lake Kyoga basin } & NASE3 & - & - & - & - & $1.80 \pm 0.05^{b c d}$ & $0.14 \pm 0.03^{\mathrm{ab}}$ \\
\hline & & TME14 & 0.00 & $0.43 \pm 0.21^{\mathrm{a}}$ & $0.85 \pm 0.04^{\mathrm{cd}}$ & $0.31^{\mathrm{ab}} \pm 0.07$ & $1.52 \pm 0.03^{\text {cde }}$ & $0.08 \pm 0.02^{\mathrm{ab}}$ \\
\hline & & NASE12 & - & - & $1.25 \pm 0.03^{\mathrm{abc}}$ & $0.48^{a} \pm 0.05$ & - & - \\
\hline & West Nile farmlands & TME204 & - & - & $0.21 \pm 0.01^{\dagger}$ & $0.18^{\mathrm{ab}} \pm 0.18$ & & \\
\hline & \multirow[t]{3}{*}{ Western Medium High farmlands } & TME14 & - & - & $1.19 \pm 0.01^{\mathrm{abc}}$ & $0.54^{\mathrm{a}} \pm 0.27$ & $1.52 \pm 0.05^{\text {cde }}$ & $0.00 \pm 0.00^{b}$ \\
\hline & & TME2961 & - & - & $1.32 \pm 0.01^{\mathrm{ab}}$ & $0.00^{\circ} \pm 0.00$ & - & - \\
\hline & & Akena & - & - & $1.32 \pm 0.05^{\mathrm{ab}}$ & $0.00^{\circ} \pm 0.00$ & - & - \\
\hline
\end{tabular}

(-) not applicable for the CGM damage score; Scores: $1=$ less than $25 \%$ of leaf surface with chlorosis; $2=$ more than $25 \%$ but less than $75 \%$ of leaf surface with chlorosis, and $3=$ over $75 \%$ of leaf surface with chlorosis; Figures with same superscript letters within a column are not significantly different.(Tukey test) 
TABLE 3. Linear regression statistics of abundance of CGM on T. aripo on cassava varieties at CGM leaf damage score two in various agro-ecological zones during April and December 2013

\begin{tabular}{llccc}
\hline Cassava variety & Agro-ecological zone & Regression coefficients & t- value & Probability \\
\hline \multirow{4}{*}{ TME14 } & Rainy season April 2013 & & & \\
& Northern Moist farmlands & -1.382 & 17.25 & $0.037^{*}$ \\
& Western Medium High farmlands & 0.610 & 111.00 & $0.006^{*}$ \\
& Dry season December 2013 & & & \\
& Northern Moist farmlands & & 0.558 \\
& Southern and Eastern Lake Kyoga basin & -0.047 & 0.64 & 0.769 \\
& Western Medium High farmlands & 16.300 & 13.40 & $0.047^{*}$ \\
NASE3 & Rainy season April 2013 & & & \\
& Southern and Eastern Lake Kyoga basin & -0.469 & 0.71 & 0.50 \\
Akena & Rainy season April 2013 & & & 0.184 \\
& Southern and Eastern Lake Kyoga basin & 1.333 & 2.00 & \\
NASE12 & Dry season December 2013 & & & $0.033^{*}$ \\
& Southern and Eastern Lake Kyoga basin & 1.451 & 19.05 & - \\
TME204 & Dry season December 2013 & & & 0.728 \\
& Northwestern farmlands & & & \\
\hline
\end{tabular}

*indicates values were significant for the cassava varieties at $P<0.05$

Hairy cassava tips were probably preferred by $T$. aripo because they offer several advantages. Hairs on plant tips have been associated with maintainance of high humidity levels (Johnson, 1975 ) and preference of hairy cassava tips by $T$. aripo may be due high humidity levels inside the cassava tips, which shield $T$. aripo from dehydration, which is an adaptation to climatic extremes (Onzo et al., 2003; Yaninek and Hanna, 2003). During encounters with preys, insect predators also use hairs on the leaves for support (MacRae and Croft, 1997) and hairy cassava tips found in the present study may provide suitable habitats for T. aripo to adequately exploit CGM prey.

It has been reported that $T$. aripo survives, develops and oviposits on pollen diet (Gnanvossou et al., 2005), and probably the hairy apices of some cassava varieties contribute to better trapping of pollen grains (Roda et al, 2003) from wild plants. This provide alternative food sources with commensurate effects on survival, longevity and fecundity of $T$. aripo. The influence of hairs on phytoseiids has been reported in other plant species, apart from cassava (Romero and Benson, 2005). There was evidence in this study that cassava varieties with non-hairy tips (glabrous) such as Bao, NASE4 and TME204 also sustained high population of T. aripo. Naturally, some cassava varieties produce exudates and these have been found to be important food for T. aripo (Onzo et al., 2003).

Among the several cassava varieties, T. aripo was consistently present on TME14 in April and December 2013 in Southern and Eastern Lake Kyoga basin at low to moderate CGM densities, but in Northern Moist Farmlands, it was present on TME14 only during April (Tables 1 and 2). The lack of TME14 to support T. aripo in the Northern Moist Farmlands may be due to variability in nutritional quality of cassava plants, caused by several factors that include stresses (Showler, 2004) and drought (Gzik, 1996) that influence the host selection behavior of insects. In very attractive host plants, higher levels of free amino acids that are essential for insect 
herbivore development and population growth, have been reported (Reay-Jones, 2007). It is further reported that where the preferred host plants co-occur, varieties with substantially higher biomass supports greater oviposition of insects suggesting there may be marked differences in plant characteristics in TME14 and other cassava varieties.

\section{CONCLUSION}

This study has shown that $T$. aripo released in Uganda from 1994-98 has persisted and could still be recovered on cassava in 2013. At the leaf damage score of 2 (moderate CGM population densities), there are inverse significant linear relationships between CGM and T. aripo population densities on TME14. These relationships indicate that the CGM densities at leaf damage score of 2 are sufficiently low for $T$. aripo to deplete CGM, demonstrating the impact of $T$. aripo. These linear relationships are applicable under a range of low host densities as occur for CGM on cassava during the rainy season in the cassava belts of Africa (Hopper and King, 1986; Yanninek et al, 1989; Wiedenmann and Smith, 1993). However, there are increasing trend in $T$. aripo and CGM population densities in Western Medium High Farmlands in April and December. This observation depicts high CGM population densities that occur particularly during the dry season that overwhelms T. aripo. From the results of our finding in this study, TME14 can be suggested as a promising cassava variety to sustain T. aripo in Southern and Eastern Lake Kyoga basin and its use in other agro-ecological zones need validation.

\section{ACKNOWLEDGEMENT}

Grateful to the Eastern Africa Agricultural Productivity Project (EAAPP) and the National Agricultural Research Organization (NARO) in Uganda for the support provided and the Association for Strengthening Agricultural Research in Eastern and Central Africa (ASARECA) facilitated the publication of this paper.

\section{REFERENCES}

Cortesero, A.M., Stapel, J.O. and Lewis, W.J. 2000. Understanding and manipulating plant attributes to enhance biological control. Biological Control 17:35-49.

Gzik, A. 1996.Accumulation of proline and pattern of alpha-amino acids in sugar beet plants in response to osmotic, water, and salt stress. Environmental Experimental Botany 36:2938.

Gnanvossou, D., Hanna, R., Dicke, M. and Yaninek, J.S. 2001. Attraction of the predatory mites Typhlodromalus manihoti and Typhlodromalus aripo to cassava plants infested by cassava green mite. Entomologia ExperimentalisetApplicata101:291-298.

Gnanvossou, D., Hanna, R.and Dicke, M. 2002. Prey-related odor preference of the predatory mites Typhlodromalus manihoti and Typhlodromalus aripo (Acari: Phytoseiidae). Experimental and Applied Acarology 27: 3956.

Gnanvossou, D., Hanna,R., Yaninek, J.S. and Toko, M. 2005. Comparative life history traits of three neotropicalphytoseiid mite when feeding on plant-derived food. Biological Control 35:32-39.

Hanna, R. and Toko, M. 2003. Africa wide classical biological control of cassava green mite-overview, accomplishments and future priorities. In: Hanna, R. and Toko, M. (Eds.). Proceedings of the $3^{\text {rd }}$ Interegional Meeting of Africa Wide Cassava Green Mite Biocontrol Project. Biological Control Centre for Africa. International Institute of Tropical Agriculture, Benin. pp. 4-12.

Hopper, K.R and King, E.G.1986. Linear functional response of Microplitis croceipes (Hymenoptera: Braconidae) to variation in Heliothis spp. (Lepidoptera: Noctuidae) density in the field. Environmental Entomology 15:476-480.

Johnson, H.B. 1975. Plant pubescence: an ecological perspective. Botany Review 41:233-238.

Kariuki, C.W., Hanna, R., Toko, M. and Ngari, B.M. 2004. The spread and persistence exotic phytoseiid, Typhlodramulus aripo Delon 
(Acari: Phytoseiidae) and its effect on cassava green mite in Kenya. Proceedings of $9^{\text {th }}$ ISTRC-AB Symposium, Kenya. pp. 693707.

Magalhaes, S. and Bakker, F.M. 2002. Plant feeding by a predatory mite inhabiting cassava. Experimental and Applied Acarology 27: 27 37.

Nyiira, Z.M. 1972. Report of investigation on cassava green mite Mononychellus tanajoa Bondar.Unpublished Report. Kawanda Research Station, Kampala, Uganda. 14pp.

Onzo, A., Hanna, R.,Zannou,I,Sabelis, M.W. and Yaninek, J.S. 2003.Dynamics of refuge use: Diurnal, vertical migration by predatory and herbivorous mites within cassava plants. Oikos 101:59-69.

Reay-Jones, F.P. F., Wilson, L.T., Showler, A.T., Reagan, T.E. and Way, M.O. 2007. Role of oviposition preference in an invasive crambid impactingtwo graminaceous host crops. Environmental Entomology 36:938-951

Riis, L., Bellotti, A.C., Bonierbale, M. and O'brien, G.M. 2003. Cyanogenic potential in cassava and its influence on a generalist insect herbivore Cyrtomenus bergi (Hemiptera: Cydnidae). Journal of Economic Entomology 96:1905-1914.

Roda, A., Nyrop, J.P. and English-Loeb, G. 2003. Leaf pubescence mediates abundance of nonprey food and the density of the predatory mite, Typhlodromus pyri. Experimental and Applied Acarology 29: 193-211.

Romero, G.Q. and Benson, W.W. 2005.Biotic interactions of mites, plants and leaf domitia. Current Opinion in Plant Biology 8:436-440.

Showler, A.T. 2004. Stress-induced host plant free amino acids and insects, pp. 2139-2142. In: Capinera, J.L. (Eds.), Encyclopedia of Entomology, vol. 3. Kluwer Academic, Dordrecht, The Netherlands.

Showler, A.T. 2002. Effects of water deficit stress, shade, weed competition, and kaolin in particle film on selected foliar free amino acid accumulations in cotton, Gossypium hirsutum (L). Journal of Chemical Ecology 28: 615-635.

Skovgard, H., Tomkiewicz, J., Nachman, G. and MunsterSwendsen, M. 1993. The dynamics of the cassava green mite Mononychellus tanajoa in a seasonally dry area in Kenya. Experimental and Applied Ecology 17:59-76.

Wiedenmann, R.N. and Smith, Jr. J.W. 1993. Functional response of the parasite Cotesia flavipes (Hymenoptera: Braconidae) at low densities of the host Diatraea saccharalis (Lepidoptera: Pyralidae).Environmental Entomology 22: 849-858.

Yaninek, J.S. and Hanna, R. 2003. Cassava green mite in Africa: Aunique example of successful biological control of a mite pest on a continental scale. Biological Control in IPM Systems in Africa. Neuenschwander, P., Borgemeister, C. and Langewald, J. (Eds.), pp. 61 - 75. CAB International, U.K.

Yaninek, J.S., de Moraes, G.J. and Markham, R.H.1989. Handbook on the cassava green mite (Mononychellus tanajoa) in Africa.A guide to its biology and procedures for implementing classical biological control. Alphabyte and Via di Donna Olympia, Rome, Italy.

Yaninek, J.S., Megevand, B. de Moreas, G.J., Baker, F., Braun, A. and Herren, H.R. 1991. Establishment and spread of the Neotropical predator Amblyseius idaeas (Acarri: Phytoseeidae) in Benin.West Africa. Biocontrol Science and Technology 1:323330.

Yaninek, J.S., Onzo, A. and Ojo, J.B. 1993. Continent wide releases of neotropical phytoseiids against the exotic cassava green mite in Africa. Experimental and Applied Acarology 17:145-160.

Zundel, C. 2006. Of mites and men. Agroecological factors affecting the neotropical predatory mite Typhlodromalus aripo DeLeon and its potential to control the cassava green mite in the mid-altitudes of Cameroon. PhD Thesis, University of Basel, Switzerland.

Zundel, C., Nagel, P., Hanna, R., Korner, F. and Scheidegger, Urs. 2009. Environment and host-plant genotype effects on the seasonal dynamics of a predatory mite on cassava in sub-humid tropical Africa. Agricultural and Forest Entomology 11:321-331. 